\title{
Diet, reproductive biology, and ecological interactions of Fritziana goeldii (Anura: Hemiphractidae)
}

\author{
Bruna Guarabyra, ${ }^{1}$ Andressa M. Bezerra, ${ }^{1}$ André Fonseca Antunes, ${ }^{2}$ and Sergio P. Carvalho-e- \\ Silva ${ }^{1}$ \\ ${ }^{1}$ Universidade Federal do Rio de Janeiro, Instituto de Biologia, Departamento de Zoologia, Laboratório de Anfíbios e Répteis. \\ 21944-902, Rio de Janeiro, RJ, Brazil. E-mail: brunaguarabyra29@gmail.com. \\ ${ }^{2}$ Universidade Federal do Rio de Janeiro, Instituto de Biologia, Departamento de Zoologia, Laboratório de Entomologia. Caixa \\ Postal 68044, Cidade Universitária, 21941-971, Rio de Janeiro, RJ, Brazil.
}

\begin{abstract}
Diet, reproductive biology, and ecological interactions of Fritziana goeldii (Anura: Hemiphractidae). Aspects of the diet, reproduction, and interactions with other taxa are reported for the egg-brooding tree frog, Fritziana goeldii, an endemic phytotelmadwelling species from southeastern Brazil. A total of 56 frogs (48 males; 8 females) was collected between December 2018 and November 2019. A total of 218 dietary items, representing at least 28 taxa was recovered. Hymenoptera and Coleoptera were the most abundant, mainly early in the year (January-April), with Formicidae being the most represented group. Parasitic interactions with ostracods and helminths were observed in 12 and 13 frogs, respectively, with most of these organisms being found in the intestines of $F$. goeldii. Fritziana goeldii is sexually dimorphic, with females $(\bar{x}=36.0 \mathrm{~mm})$ being larger than males $(\bar{x}=28.3 \mathrm{~mm})$. All females collected had oocytes, and two also had eggs attached to the dorsum. No relation was found between the female's size and size and number of oocytes. The reproduction of $F$. goeldii seems to be prolonged, with males calling throughout the year.
\end{abstract}

Keywords: Egg-brooding tree frog, food habits, ostracods, parasitism, phoresy, South America.

\footnotetext{
Resumo

Dieta, biologia reprodutiva e interações ecológicas de Fritziana goeldii (Anura: Hemiphractidae). Aspectos da dieta, reprodução e interações com outros táxons foram reportados para a perereca marsupial Fritziana goeldii, uma espécie bromelígena endêmica da região sudeste do Brasil. Um total de 56 indivíduos (48 machos; 8 fêmeas) foram coletados entre dezembro de 2018 e novembro de 2019. Um total de 218 itens alimentares, representando pelo menos 28 táxons, foram identificados. Hymenoptera e Coleoptera foram os táxons mais abundantes, principalmente nos primeiros meses do
} 
ano (janeiro-abril), com Formicidae sendo o grupo mais representativo. Interações com ostrácodes e helmintos foram observadas em 12 e 13 indivíduos, respectivamente, com a maior parte desses organismos sendo encontrados no intestino dos espécimes de F. goeldii. Fritziana goeldii apresenta dimorfismo sexual, com as fêmeas $(\bar{x}=36.0 \mathrm{~mm})$ sendo maiores que os machos $(\bar{x}=28.3 \mathrm{~mm})$. Todas as fêmeas coletadas apresentavam ovócitos, e duas também tinham ovos aderidos no dorso. Nenhuma relação foi encontrada entre o tamanho das fêmeas e o tamanho e número de ovócitos. A reprodução de $F$. goeldii aparenta ser do tipo prolongada, com machos vocalizando em todos os meses ao longo do ano.

Palavras-chave: América do Sul, foresia, hábitos alimentares, ostrácodes, parasitismo, pererecamarsupial.

\section{Introduction}

Several studies have sought to understand the interspecific relationships of anurans by studying natural history (Kehr and Hamann 2003, Freitas et al. 2008). Knowledge of foraging modes, ecological interactions, and diet composition is a vital part of a species' natural history, and helps us to understand the intra- and interspecific relationships of the frogs. (Anderson and Mathis 1999, Teixeira and Vrcibradic 2003, Mendonça et al. 2020).

Most adult anurans can be described as generalist and opportunistic predators, consuming mainly arthropods (Solé and Rödder 2009). Plant material and fruits also are often found in their diet, usually consumed accidentally along with prey, with only a few studies showing an active intake of plants by frogs (e.g., Das 1996, Silva and Britto-Pereira 2006). Prey quantity and quality can change according to seasonality and the type of environment in which the individuals are found (Duellman and Trueb 1994). The feeding strategies of frogs also may vary, with species actively searching for prey or using the sit-andwait strategy (Toft 1980, Vaz-Silva et al. 2005).

Another kind of interaction is phoresy, an interaction like commensalism in which one individual acts as a host or vector and the other as the phoretic, adhering to the host's body to be transported to another location, leading to its dispersal (Houck and O'Connor 1991, Sabagh et al. 2012). In amphibians, phoresy is mainly reported for species related to phytotelmic environments, such as bromeliads, where the accumulation of water and debris provides a microhabitat for many species of invertebrates and vertebrates (Oliveira et al. 1994, Kitching 2000, Lopez et al. 2005, Araújo et al. 2019). Whether using bromeliads exclusively for refuge and feeding (bromelicolous species) or to carry out their entire life cycle (bromeligenous species), amphibians are suitable hosts for the phoretic invertebrate fauna present in the phytotelmic community, such as microcrustaceans, annelids, and ciliates (Lopez et al. 2002, Sabagh et al. 2011, Moroti et al. 2019).

Parasitism is a frequent interaction in nature. In addition to causing diseases, parasites regulate host populations by influencing their rates of mortality and birth, nutrition, and growth, stabilizing the food chains, and structuring animal communities (Minchella and Scott 1991, Tavares et al. 2016). The relationship between parasite and host also may elucidate aspects (e.g., habitat, feeding pattern, and main predators) of the parasitized species' biology and habits (Minchella and Scott 1991, Leivas et al. 2018, Goldberg and Bursey 2019). Studies addressing the actual diversity of parasitic species and their potential hosts are necessary to understand how these interactions arose and what the consequences are for the parasitized individual (Campião et al. 2015); only a few studies have explored these interactions in amphibian species (e.g., Campião et al. 2014, 2015, 2016). 
The reproductive biology of species is a significant part of its natural history (Haddad and Prado 2005). Anurans have 41 described reproductive modes, with neotropical frogs having the greatest diversity (Pombal and Haddad 2005, Malagoli et al. 2021). A reproductive strategy is defined as the combination of morphological and physiological attributes that act together to produce an optimum number of offspring in specific environmental conditions (Duellman and Trueb 1994). Reproductive biology includes the reproductive temporal pattern-i.e., prolonged or explosivethe time of day when the males call, the calling site, and sexual dimorphism (Haddad 1991).

Hemiphractidae occurs in tropical regions of Central and South America and currently comprises six genera in two subfamilies (Castroviejo-Fisher et al. 2015, del Pino 2018, Walker et al. 2018, Frost 2020). The genus Fritziana belongs to the subfamily Hemiphractinae, which currently is composed of seven endemic species of the Brazilian Atlantic Forest (Folly et al. 2018, Frost 2020). Fritziana goeldii is endemic to southeastern Brazil and includes three population lineages; its range encompasses the lowlands and slopes of the mountains to elevations of 2,200 $\mathrm{m}$ a.s.l. in the states of São Paulo and Rio de Janeiro (Walker et al. 2018, Frost 2020). These frogs are nocturnal and can be found among bromeliad leaves or in crevices of tree bark, and like other members of the family, the females carry eggs on their backs until the tadpoles hatch-hence they are called egg-brooding tree frogs (Weygoldt and Carvalho-e-Silva 1991, Castroviejo-Fisher et al. 2015, Walker et al. 2018).

Although Fritziana goeldii is the best-known species of the genus (Walker et al. 2016); however, little is known about its natural history other than egg development (Duellman and Gray 1983, Weygoldt and Carvalho-e-Silva 1991) and tadpole feeding behavior (Weygoldt 1989). According to the IUCN Red List (IUCN 2021), the species is categorized as Least Concern, with a stable population. However, Walker et al.
(2018) recognized three lineages within $F$. goeldii, calling attention to the possibility of cryptic diversity and suggesting changing the species status to Data Deficient.

We investigated the natural history of a population of Fritziana goeldii from the state of Rio de Janeiro in southeastern Brazil, focusing on the diet and ecological interactions of the species and its reproductive biology. Our goals were to: (1) describe the composition of the diet of F. goeldii; (2) identify variations in the composition of the diet through the year; (3) describe the ecological interactions of the frog; (4) ascertain whether the numbers and sizes of oocytes are correlated with female body size; and (5) determine whether there is sexual dimorphism in body size.

\section{Materials and Methods}

\section{Sampling}

The study was carried out at the Parque Nacional da Tijuca (PNT) $\left(23^{\circ} 35^{\prime} 15.89^{\prime \prime} \mathrm{S}, 43^{\circ}\right.$ $288^{\prime} 58.59^{\prime \prime} \mathrm{W}$ ) in the state of Rio de Janeiro in southeastern Brazil. This fragment of Atlantic Forest is divided into three sections (ICMBio 2020): Serra da Carioca, Pedra Bonita/Pedra da Gávea, and Floresta da Tijuca; the latter was our study site, which was selected based on prevalence of bromeliads, the most common habitat for this species.

The frogs were identified as Fritziana goeldii by their possession of interorbital triangle with a bilobed blotch, dark brown half-moon-shaped spot in the sacral region, and median transverse dark brown stripes on thighs, shanks, and feet (Figure 1; Folly et al. 2014, Walker et al. 2018). They are likely part of the $F$. goeldii lineage from the coastal regions of Rio de Janeiro (Go-II lineage in Walker et al. 2018).

The fieldwork was conducted once a month from December 2018 to November 2019, always starting around 17:30/18 $\mathrm{h}$ and lasting around 4 hr. During the first 2 months (2018 December and 2019 January), the individuals were collected 


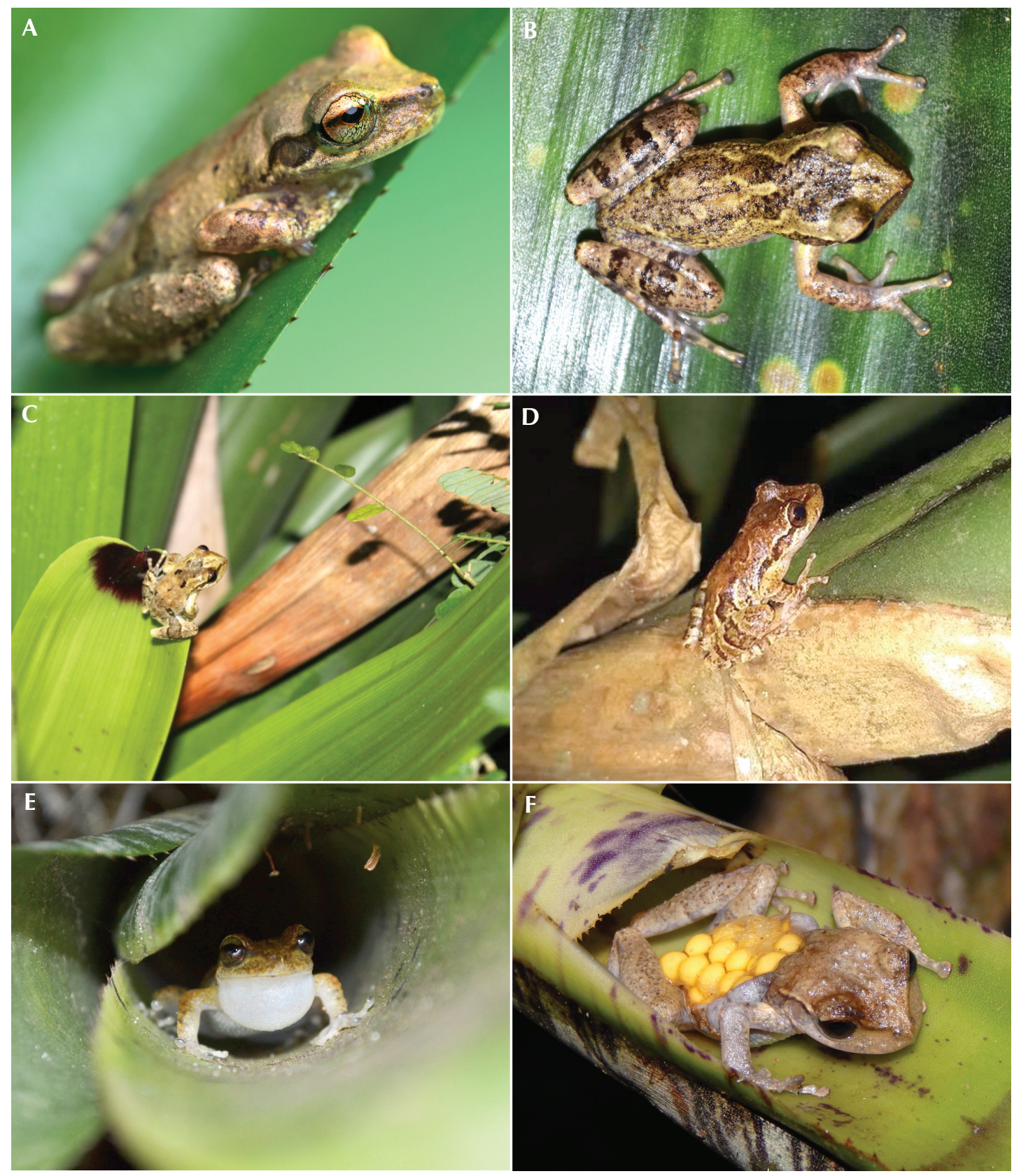

Figure 1. Individuals of $F$. goeldii found at Parque Nacional da Tijuca, Rio de Janeiro state, southeastern Brazil. (A-C) Individuals found on bromeliad leaves; (D) individual in a bromeliad base; (E) a calling male; (F) a female with eggs on her back. Photos: Luis Felipe Peixoto (A), Isabela C. Rocha (B), Lucas O. Passos (C), Andressa M. Bezerra (D), Isabela C. Rocha (E), and Ariel Wendt (F). 
under a permit that allowed up to 20 individuals per year (ICMBio\#65470-1). The individuals collected in the subsequent months were under a second license (ICMBio\#69339-1), which limited the sample to as many as 48 individuals per year. Because of this limitation, in the first 2 mo, we collected up to 10 frogs/month, and in the subsequent months, we collected only the first five individuals encountered (whenever possible), although other individuals may have been encountered.

We actively searched for the frogs. The species of bromeliads were identified following Sabagh et al. (2017). The frogs were collected by hand, euthanized with $5 \%$ lidocaine, and fixed in $10 \%$ formaldehyde, thereby inhibiting digestion of their gastrointestinal contents. After $72 \mathrm{hr}$, the specimens were preserved in $70 \%$ ethanol. All procedures followed the practice guidelines of Conselho Nacional de Controle de Experimentação Animal - CONCEA. Voucher specimens were deposited at the amphibian collection of Laboratório de Anfíbios e Répteis, Departamento de Zoologia, Instituto de Biologia, Universidade Federal do Rio de Janeiro (ZUFRJ).

\section{Diet}

Gastrointestinal tracts of the frogs were removed, and the stomach and intestine contents were analyzed separately under a Leica stereoscopic microscope. Because several studies use methods such as stomach flushing to evaluate species diet, relying exclusively upon stomach contents, we wanted to investigate whether the inclusion of intestinal content be useful to find food items not encountered in the frog's stomach.

Food items were identified to the lowest possible taxonomic level with keys mentioned below. When possible, the length and width of the food items were measured to estimate their volumes based on the ellipsoid volume formula: $\mathrm{V}=(4 \pi / 3)(\mathrm{L} / 2)(\mathrm{W} / 2)^{2}$, where $\mathrm{V}$ is the prey volume, $\mathrm{L}$ its length, and $\mathrm{W}$ its width. We also calculated the Index of Relative
Importance (IRI) of the food items with the following formula: $\mathrm{IRI}=(\mathrm{PO})(\mathrm{PI}+\mathrm{PV})$, where $\mathrm{PO}$ is the percentage of occurrence (= frequency), PI is the percentage of individuals (= absolute number), and PV is the percentage of the volume of each measured item (Solé and Rödder 2009). When it was impossible to calculate the volume of a food item owing to the advanced stage of fragmentation or digestion, only the absolute number and frequency were calculated (Solé and Rödder 2009). Given that there is no record of active plant intake by Fritziana goeldii, stomachs and intestines containing only plant material were classified as empty.

The expected taxon richness in Fritiziana goeldii's diet was calculated based on an extrapolation sampling curve using the iNEXT package in R environment (Hsieh et al. 2020, R Core Team 2020). To run this analysis, we used a matrix of sampling-units incidence, with $95 \%$ confidence interval. We performed the extrapolation sampling curve with the food items that were identified to the most specific level possible as the operational taxonomic units (UTOs), if there was no overlap between taxa, totaling 28 UTOs.

Non-insect arthropods were identified with Brusca et al. (2016), and hexapods were identified with the key to orders and images in Rafael et al. (2012) and Triplehorn et al. (2005). To compare the frequency of taxa of food items during the study, the number of frogs having a particular organism in the stomach and/or intestine was divided by the number of frogs collected in that month. Data were standardized by using the highest taxonomic level-in this case, order-except for the class Chilopoda, which was not identified at a lower taxonomic level. To visualize the taxa frequency through time we generated a heat map using ggplot2, hrbrthemes, tibble and reshape packages (Wickham 2007, 2016, Müller and Wickham 2020, Rudis 2020) in $\mathrm{R}$ environment ( $\mathrm{R}$ Core Team 2020). 


\section{Reproductive Biology}

The frog's sex was determined by examining the gonads (Figure 2) and by the presence of vocal slits in preserved males. The snout-vent length (SVL) of each individual was measured with digital calipers (to the nearest $0.1 \mathrm{~mm}$ ). The eggs and oocytes of females were counted and measured with the aid of a Leica stereomicroscope under a 0.63 or 1.0 magnification.

We performed an Analysis of Variance (ANOVA) to test for sexual dimorphism in body size. Spearman's correlation coefficient was used to determine whether the sizes and numbers of oocytes were correlated with female body size, because the data were not normally distributed according to results of the Shapiro-Wilk Normality Test. All analyses were conducted in the $\mathrm{R}$ environment (R Core Team 2020). We considered a $p<0.05$ significant for the ANOVA and Spearman's correlation coefficient. Only the number of oocytes was included in the correlation test because all females had oocytes, but only two had eggs. Results are shown in a boxplot and linear regression, respectively, both generated using the ggplot2 package in $\mathrm{R}$ environment (Wickham 2016, R Core Team 2020). Individuals from the ZUFRJ amphibian collection collected in previous expeditions at the same location (PNT) from 2016 and 2018 were also included in the analysis to increase the ANOVA accuracy (Appendix I).

To determine whether Fritziana goeldii reproductive activity is prolonged (i.e., all year) or seasonal, we observed whether males were calling (as a proxy of mating activity) in the sites visited in each survey.

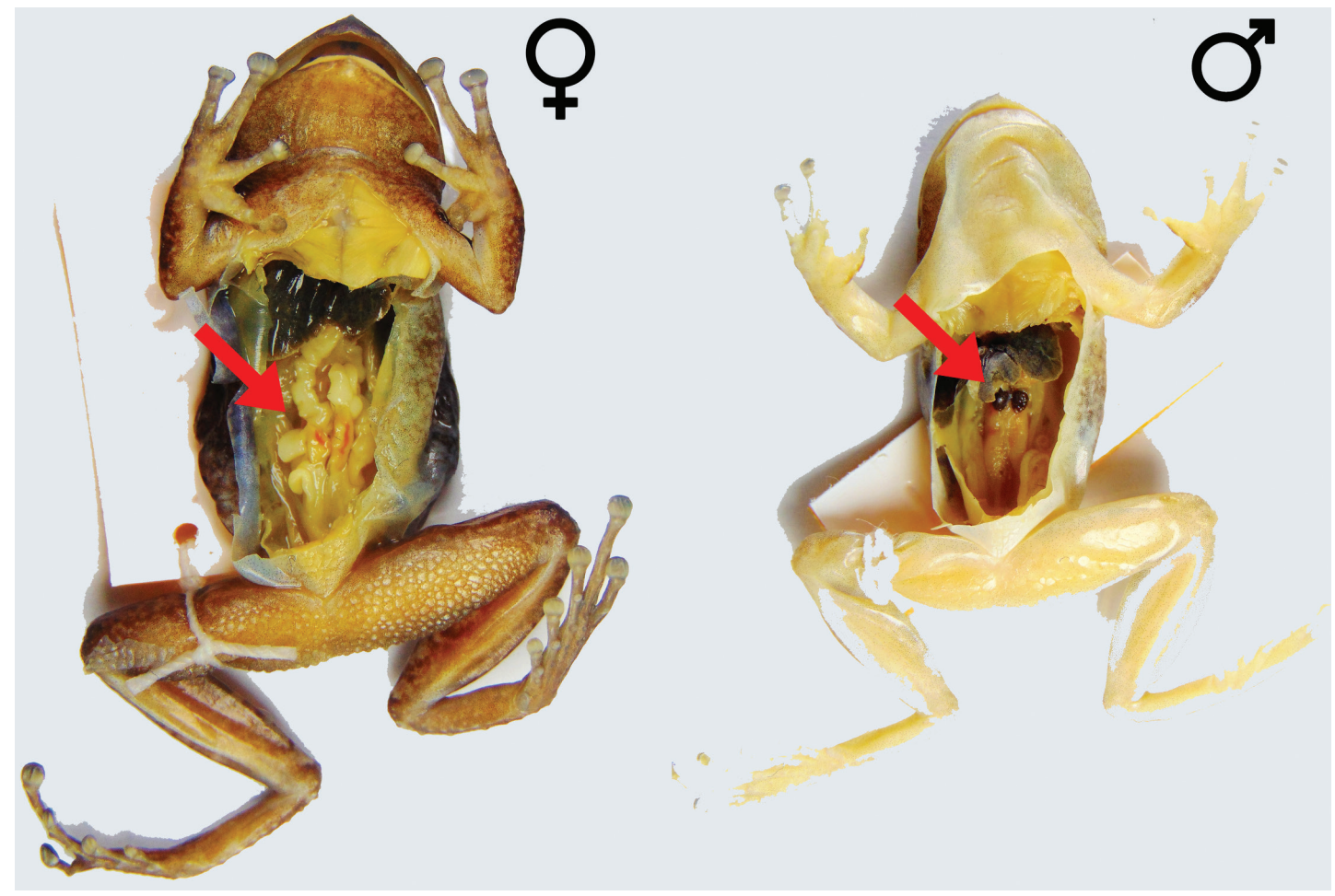

Figure 2. Female (F16792) and male (F16598) gonads (arrows) of Fritziana goeldii from Floresta da Tijuca southeastern Brazil. 


\section{Results}

\section{Diet}

We collected 56 specimens of Fritziana goeldii during the 12 surveys (Appendix); 48 are males, with SVLs ranging from $22.3-32.7 \mathrm{~mm}$ $(\bar{x}=28.3 \pm 1.8 \mathrm{~mm})$ and 8 females with SVLs ranging from $33.7-39.5 \mathrm{~mm}(\bar{x}=36.0 \pm 3.2$ $\mathrm{mm})$. Of the 56 gastrointestinal tracts examined, $53(94.6 \%)$ had identifiable material in at least one of the organs (i.e., stomach and/or intestine); 6 individuals had food only in the stomach $(11.3 \%), 18$ only in the intestine $(33.9 \%)$, and 29 in both organs $(54.7 \%)$. We identified a total of 218 food items, representing at least 28 taxa belonging to 13 orders and four subphyla, with most identified at the familial level (Table 1).

Among the food items, Hymenoptera was the most frequent and had the highest index of relative importance (IRI), with Formicidae being the most representative group. Coleoptera had the second highest frequency and IRI, followed by Araneae and Blattodea, respectively (Table 1, Figure 3). Formicidae and Coleoptera were more frequent than the other taxa from January-April and Araneae in April and June (Figure 3). Other food items appeared in low frequency and were restricted to just 1 mo; examples are Odonata in May, Mantodea in August, and Chilopoda in April (Figure 3).

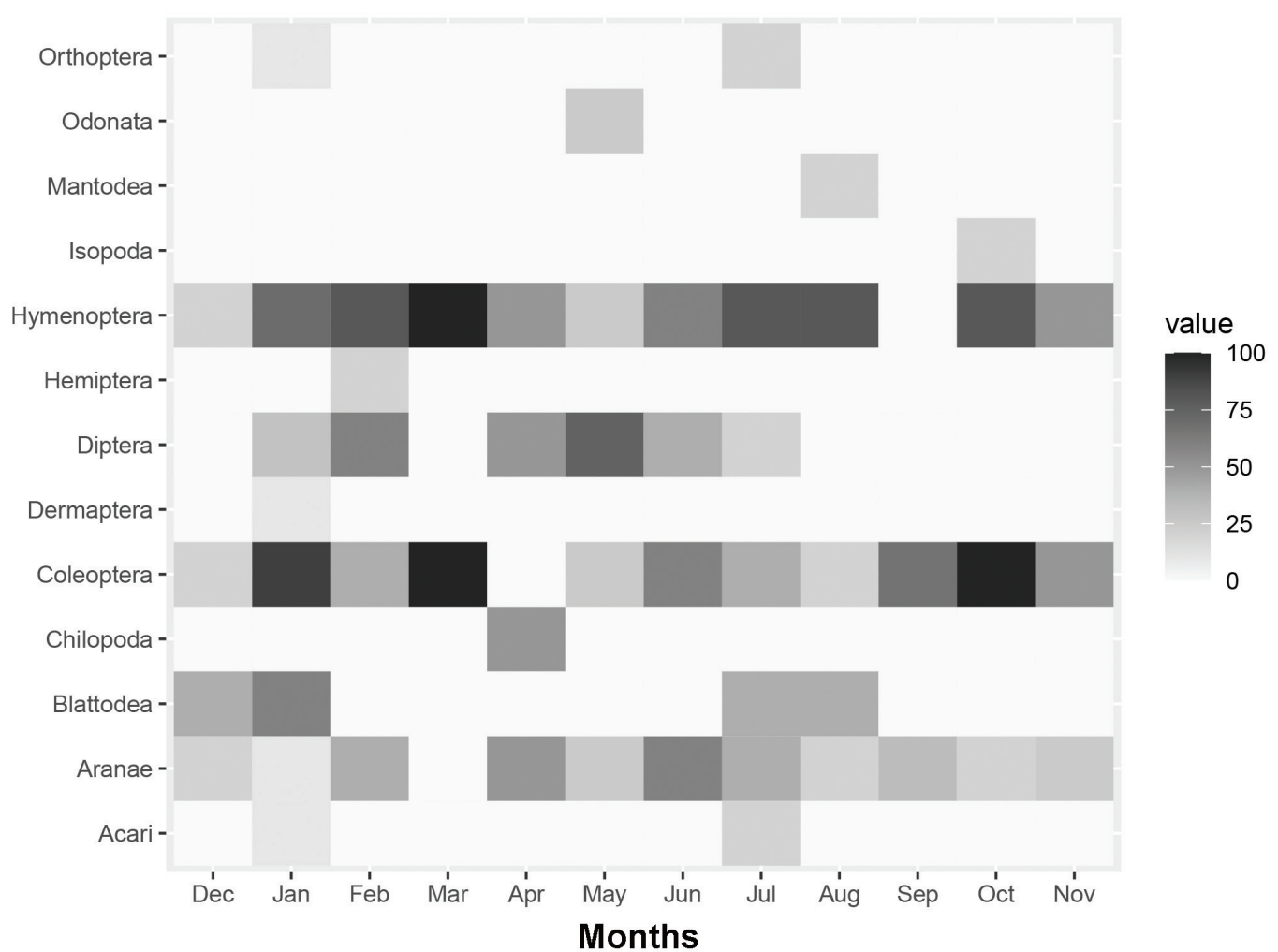

Figure 3. Heat map showing variation in the frequency of occurrence of each taxon per month. Dark grey indicates a higher frequency of the taxon in each month. 
Guarabyra et al.

Table 1. Food items found with their respective values in absolute number (N), relative volume (V), frequency of occurrence $(\mathrm{F})$ and relative importance index (IRI).

\begin{tabular}{|c|c|c|c|c|}
\hline & $N(\%)$ & $V(\%)$ & $\mathbf{F}(\%)$ & IRI \\
\hline \multicolumn{5}{|l|}{ CHELICERATA } \\
\hline Acari & $2(0.91)$ & - & $2(3.57)$ & - \\
\hline Aranaeae & $21(9.63)$ & $249.49(68.15)$ & $18(32.14)$ & 509.84 \\
\hline Araneidae & $3(1.37)$ & $168.87(46.13)$ & $3(5.35)$ & 254.14 \\
\hline Corinnidae & $2(0.91)$ & $71.02(19.4)$ & $1(1.78)$ & 35.15 \\
\hline Salticidae & $1(0.45)$ & - & $1(1.78)$ & - \\
\hline \multicolumn{5}{|l|}{ HEXAPODA } \\
\hline Blattodea & $13(5.96)$ & $67.33(18.38)$ & $11(19.64)$ & 300.75 \\
\hline Isoptera & $4(1.83)$ & $9.28(2.53)$ & $2(3.57)$ & 15.58 \\
\hline Termitidae & - & - & $1(1.78)$ & - \\
\hline Coleoptera & 19(28.56) & $98.75(26.97)$ & $27(48.2)$ & 713.8 \\
\hline Polyphaga & $15(6.88)$ & $90.5(24.7)$ & 11(19.64) & 619.11 \\
\hline Staphylinoidea & $2(0.91)$ & - & $2(3.57)$ & - \\
\hline Curculionidae & - & - & $1(1.78)$ & - \\
\hline Elateridae & $1(0.45)$ & $21.7(7.6)$ & $1(1.78)$ & 11.33 \\
\hline Scarabeidae & - & - & $3(5.35)$ & - \\
\hline Scirtidae & $1(0.45)$ & - & $1(1.78)$ & - \\
\hline Tenebrionidae & $6(2.75)$ & 68.8(18.79) & $6(10.7)$ & 230.69 \\
\hline Lagriinae & $1(0.45)$ & - & $1(1.78)$ & - \\
\hline Carabidae & - & - & $3(5.35)$ & - \\
\hline Dermaptera & $1(0.45)$ & - & $1(1.78)$ & - \\
\hline Diptera & - & - & 11(19.64) & - \\
\hline Brachycera & - & - & $5(8.92)$ & - \\
\hline Chironomidae & - & - & $3(5.35)$ & - \\
\hline Tipulomorpha & - & - & $7(12.5)$ & - \\
\hline Tipulidae & - & - & $2(3.57)$ & - \\
\hline Limoniidae & - & - & $2(3.57)$ & - \\
\hline Hemiptera & - & - & $1(1.78)$ & - \\
\hline Reduviidae & - & - & $1(1.78)$ & - \\
\hline Hymenoptera & $56(25.69)$ & $21.92(5.97)$ & $50(89.27)$ & 1329.69 \\
\hline Ichneumonoidea & $2(0.91)$ & $6.62(1.8)$ & $2(3.57)$ & 9.7 \\
\hline Formicidae & $53(24.31)$ & $15.3(4.17)$ & $43(76.78)$ & 1319.99 \\
\hline Apoidea & $1(0.45)$ & - & $1(1.78)$ & - \\
\hline Mantodea & - & - & $1(1.78)$ & - \\
\hline
\end{tabular}


Table 1. Continued.

\begin{tabular}{|c|c|c|c|c|}
\hline & $\mathrm{N}(\%)$ & $\mathrm{V}(\%)$ & $F(\%)$ & IRI \\
\hline Thespidae & - & - & $1(1.78)$ & - \\
\hline Odonata & $1(0.45)$ & $8.39(2.29)$ & $1(1.78)$ & 4.88 \\
\hline Orthoptera & $1(0.45)$ & - & $3(5.35)$ & - \\
\hline Gryllidae & - & - & $2(3.57)$ & - \\
\hline Trigonidiidae & $1(0.45)$ & - & $1(1.78)$ & - \\
\hline \multicolumn{5}{|l|}{ CRUSTACEA } \\
\hline Oniscidea & $1(0.45)$ & $0.92(0.25)$ & 1(1.78) & 1.24 \\
\hline \multicolumn{5}{|l|}{ MYRIAPODA } \\
\hline Myriapoda & $2(0.91)$ & $11.05(3.01)$ & $3(5.35)$ & 20.9 \\
\hline Chilopoda & $2(0.91)$ & $11.05(3.01)$ & $2(3.57)$ & 13.9 \\
\hline Newportiidae & $1(0.45)$ & $11.05(3.01)$ & $1(1.78)$ & 6.17 \\
\hline
\end{tabular}

The extrapolation sampling curve estimated 40 taxa as potentially part of the diet of Fritziana goeldii with the confidence interval varying from 29-53 taxa (Figure 4).

\section{Ecological Interactions}

Most frogs were found in the following species of bromeliads-Aechmaea nudicaulis, Quesnelia marmorata and Vriesea bituminosa.

Ostracods of the genus Elpidium were found in 12 frogs. Two had ostracods either inside their intestine or adherent to their skin externally; eight had ostracods only in the intestines and two had Elpidium in both their intestines and stomach. Most Elpidium found in the gastrointestinal tracts were intact and varied from 1-12 ostracods in the intestine and from 1 or 2 in the stomach.

We collected 13 Fritziana goeldii with helminths, which were identified as Nematoda. One frog was captured with a nematode under the skin of its head and another had a nematode in its eye. However, most helminths were found in the intestines of the frogs; only one frog had nematodes both in the stomach and intestines. In one individual, the nematodes were present inside the body cavity, but outside the gastrointestinal tract.

\section{Reproductive Biology}

The difference between the body size of females and males was highly significant $(p<$ 0.001 ), with no overlap between the values (Figure 5). All females were collected from bromeliads and had oocytes in the oviducts; two also had eggs on their backs (Figure 1F). The number of oocytes ranged from 10-19 $(\bar{x}=15.2 \pm 1.4, N=8)$ per female and the number of eggs ranged from 12-20 $(\bar{x}=16.0 \pm 5.7, N=2)$. The sizes of oocytes ranged from $0.8-4.3 \mathrm{~mm}(\bar{x}=2.7 \pm 1.2 \mathrm{~mm}$, $N=107)$ and the sizes of eggs from 3.6-4.9 $\mathrm{mm}(\bar{x}=4.2 \pm 0.3 \mathrm{~mm}, N=23)$. Sizes and numbers of oocytes were not significantly correlated with the female size $(p=0.27$ and $p=0.27$, respectively) (Figure 6).

We heard and saw males calling from bromeliad leaves every month of the study (Figure 1). Even when the individuals were found at lower densities, it was possible to hear males calling from farther away and/or at greater heights. 


\section{Discussion}

Walker et al. (2018) found three lineages within Fritziana goeldii-one from the state of São Paulo and two from Rio de Janeiro. Although there is no specimens from the Parque Nacional da Tijuca included in the analysis of Walker et al. (2018), we believe that the subpopulation sampled in our study belongs to the lineage from

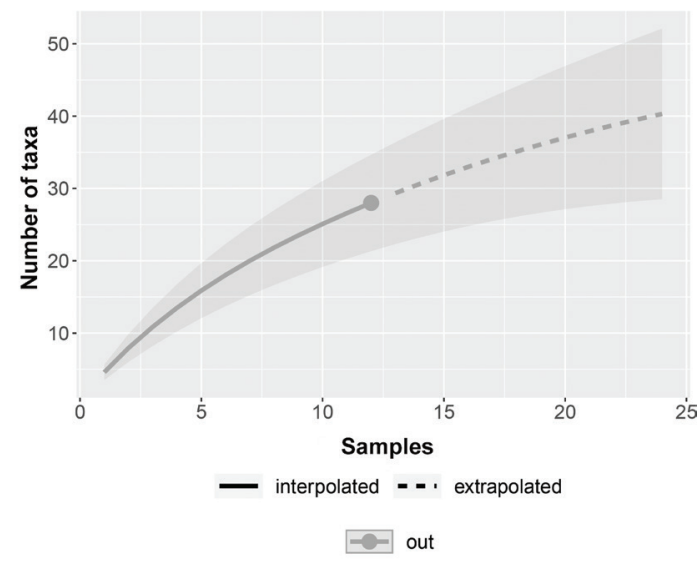

Figure 4. Accumulation curve of taxa present in the diet of specimens of Fritziana goeldii collected at Parque Nacional da Tijuca, southeastern Brazil. the coastal regions of Rio de Janeiro (Go-II) based on the PNT location. Based on the number of individuals found (sampled and seen) during this study and the fact that the PNT is a National Conservation Unit, we think that this subpopulation is Least Concern and Stable according to the IUCN criteria (IUCN 2021).

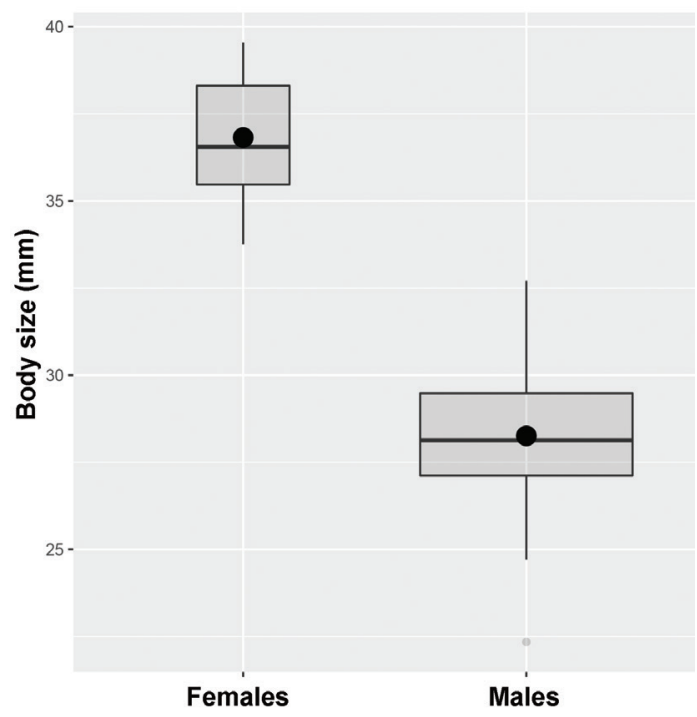

Figure 5. Difference in body size between females (F) and males $(M)$. Black circles indicate the mean and bold lines the median.
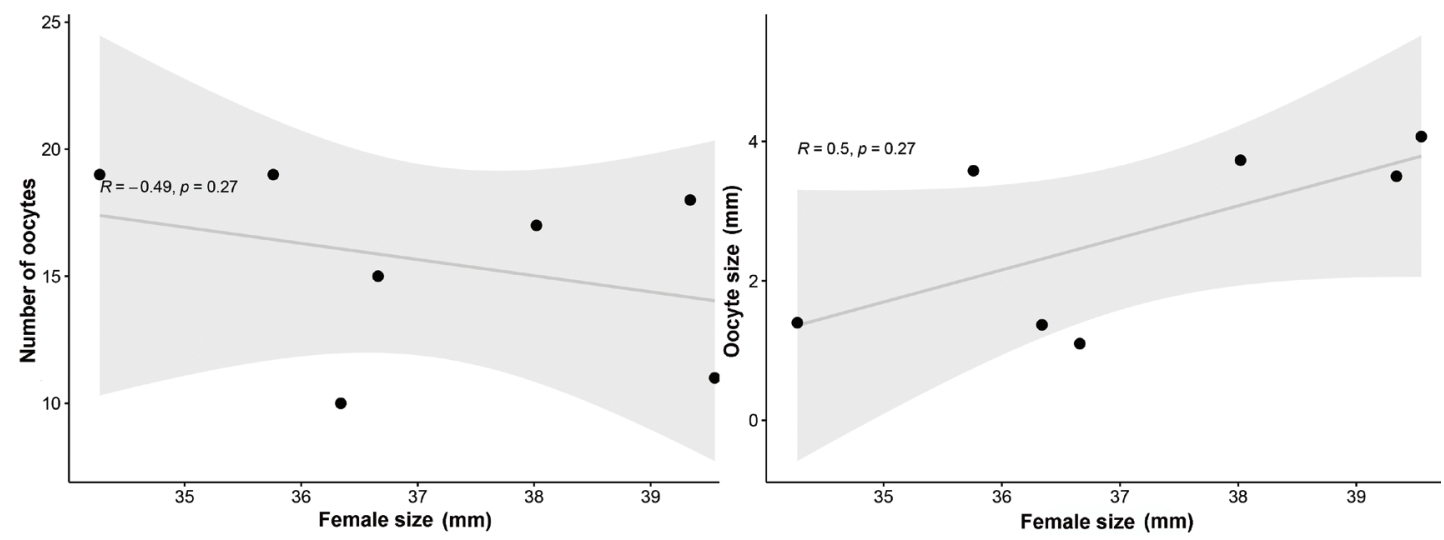

Figure 6. Linear regression between the number of oocytes, oocyte size and female size. Both correlations were not significant $(p>0.05)$. Trend lines in light grey, and confidence interval in shades of grey. 


\section{Diet}

We observed that the most prevalent food items in the diet of Fritziana goeldii are specimens with more resistant body structuresi.e., beetles and arachnids. This is explained by the accelerated digestion process that the items go through when they reach the stomach. More delicate parts and sensitive tissues are digested faster, leaving in the intestine more rigid structures such as elytra, heads, sclerites and legs (Solé et al. 2005). Consequently, prey with soft bodies tend to be underestimated (Solé and Rödder 2009).

Anurans with an active foraging strategy tend to feed on small prey that are less agile and live in groups; these prey items have a body rich in chitin but low in energy content. Active foragers usually have a greater number of food items per stomach/intestine than do sit-and-wait predators (Toft 1981, Solé and Rödder 2009). The diversity of food items in the diet of Fritziana goeldii is mainly composed of ants, beetles, and arachnids, indicating that the species is a foraging generalist (sensu Weygoldt and Carvalho-e-Silva 1991). Arthropods, such as spiders, ants and beetles, are highly abundant in the environment, with beetles having the greatest diversity within Insecta and therefore a typical food item for neotropical anurans (Teixeira et al. 2009, Martins et al. 2010, Almeida et al. 2019, Moser et al. 2019). Representatives of these taxa were present almost every month in the diet of Fritziana goeldii and had the highest IRI values (Table 1, Figure 3).

As expected, the inspection of both the stomach and intestine yielded many more taxa of food items, because some (e.g., Odonata and Hemiptera) were found only in the intestine. Ostracods were mainly observed in the intestine; this probably reflects the resistance of their body parts to digestion, such as the head and elytra of Odonata and Hemiptera, respectively, and the outer carapace of Ostracoda (made of chitin and calcium carbonate).
Most diet studies usually identify prey to the ordinal level (e.g., Solé and Rödder 2009, Batista et al. 2011, Oliveira et al. 2017, Pacheco et al. 2017); probably this is because the food items are found at an advanced stage of digestion. We were able to identify most $(78.5 \%)$ prey at the familial level. This result contributes not only to knowledge of the diet of Fritziana goeldii, as well as the faunal diversity of the frogs' habitat. Thus, studies that aim to understand how environmental disturbances could affect the availability of prey, and consequently, the population of $F$. goeldii and other anurans in that location (Kittel and Solé 2015) are enabled.

Hymenoptera and Coleoptera were the most frequent taxa in the diet between January and March and between July and October. Araneae is more frequent between April and July. A higher frequency in the first months may have been influenced by the fact that in January, we collected 10 Fritziana goeldii, instead of five in the other months; thus, the greater number of food items obtained probably reflects the frequency of the observed taxa.

The species accumulation curve probably is not stabilized owing to the need of a greater sampling effort, both in the numbers of days and individuals. In addition, we know that the advanced digestion of food items hinders the process of identifying prey and may underestimate the absolute richness of species. A larger sample would also enable the identification of more items to the most specific level possible (Solé and Rödder 2009).

Abiotic factors, such as the seasonal availability of prey in the environment, also can influence the diet pattern of anurans (Toft 1980, Freitas et al. 2008). Because several taxa were found in the diet of Fritziana goeldii throughout the year, its feeding strategy appears to be generalist and opportunistic. However, we could not properly evaluate the selectivity index because we did not sample the proportion of prey items available at the study site (Simon and Toft 1991). 


\section{Ecological Interactions}

Phoresy has been observed between ostracods of the genus Elpidium and several anuran species, including the egg-brooding tree frog Fritziana goeldii (Lopez et al. 2005, Sabagh et al. 2011, Sabagh and Rocha 2014, Araújo et al. 2019, Moroti et al. 2019). Fritziana goeldii was the first anuran species for which adult ingestion of ostracods was reported (Guarabyra et al. 2020). It is still unknown whether these microcrustaceans in the gastrointestinal tract could be explained by accidental or intentional ingestion (i.e., as part of their diet); thus, we chose not to include the ostracods found in the gastrointestinal tract of $F$. goeldii as food items. Further studies on the fecal content of $F$. goeldii are necessary to confirm whether there is dispersion through the passage of the digestive tract.

This study is the first record of interaction between nematodes and Fritziana goeldii. Because all nematodes occurred either under the skin or organs of $F$. goeldii, we think that the nematodes were parasitic. The study of parasites in amphibians is uncommon, and more frequent for temperate-zone species (Aguiar et al. 2014). In tropical regions, most interactions between nematodes and frogs reports the nematodes parasitizing gastrointestinal tracts of frogs (Tavares et al. 2016). Recently published works probably underestimate the diversity of parasites because they are difficult to identify and require the use of diagnostic tools other than external morphology (e.g., molecular analysis, phylogenetics, and bioassays approaches;

Tavares et al. (2016).

\section{Reproductive Biology}

The few females collected may reflect their habit of foraging in the leaf litter when they are active, as observed by Weygoldt and Carvalhoe-Silva (1991). Females with eggs on their backs are in the first phase of egg maturation in which the eggs are yellow as is characteristic of yolk
(Figure 1F). During this phase, the females remain inside bromeliads until the eggs mature and the embryos begin to develop, and the eggs become darker in color (Weygoldt and Carvalhoe-Silva 1991). The females that we found that did not have eggs on their backs had well-formed oocytes, indicating that they could be in the bromeliads to mate, attracted by a calling male.

In contrast to females, males are naturally more exposed because they perch on the leaves of bromeliads and call to attract females and search for food. We only captured the first five or ten that we first encountered; it is possible that we found males more easily than females, leading to a greater number of males collected.

Given the limited number of Fritziana goeldii that were allowed to collect, no statistical analyses were carried out involving individuals per month. Furthermore, seasonality is not marked in southeastern Brazil (Sant'Anna Neto 2005). Nevertheless, environmental factors such as temperature, rainfall and humidity vary daily, and the parameters recorded on any one day may not represent the entire month.

The dimorphism in male and female body sizes in Fritziana goeldii was expected, given that about $90 \%$ of anuran species exhibit sexual dimorphism in body size (Shine 1979). Many factors can influence this difference in size and most of them have been addressed extensively in the literature. Examples include larger females producing larger eggs and spawning, leading to greater fertility (Crump 1974), and small males being able to expend their "extra" energy with vocalization and territorial defense (Woolbright 1983, Freitas et al. 2008).

The number of eggs we found in Fritziana goeldii is consistant with the numbers reported in the studies of Weygoldt and Carvalho-e-Silva (1991) and Duellman and Gray (1983). The wide variation found in the sizes of the oocytes reflects the stage of development of these in each female. As the accumulation of yolk increases, so does the size of the oocytes (Weygoldt 1989). Weygoldt and Carvalho-e-Silva (1991) also commented that the size and number of eggs in 
$F$. goeldii seem to vary and that the same female can produce a different number of eggs in each reproductive encounter.

We found no significant relationship between the size of the female and the size and number of oocytes, contrary to the findings in studies of other species (e.g., Praderio and Robinson 1990, Prado et al. 2000, Rodrigues et al. 2003, Han and Fu 2013). This may have resulted from the high variability of our sample as reported by Weygoldt and Carvalho-e-Silva (1991), or by the low number of females sampled.

\section{Conclusions}

The diet of Fritiziana goeldii is that of a generalist that consumes a wide variety of prey, especially hymenopterans, coleopterans, and arachnids. Although the species accumulation curve is not stabilized owing to small sample sizes, it was possible to identify at the familial level many food items, thereby characterizing for the first time the diet of this frog. Interactions with phoretic and parasitic individuals were confirmed, but further studies are needed to identify the species of parasites present and understand what leads to these interactions and the consequences for both individuals of $F$. goeldii and the organisms that interact with this species. The reproduction of $F$. goeldii seems to be prolonged, with males singing all year. Male and female $F$. goeldii are sexually dimorphic in size, but no relationship between the size of the female and the sizes and numbers of oocytes was found. Future studies that seek to understand the relationship between abiotic and biotic factors and the reproductive period of $F$. goeldii are critical to supplement the limited knowledge about the natural history of this endemic species in southeastern Brazil.

\section{Acknowledgments}

We are grateful to Jorge Luiz Nessimian, Leandro Lourenço Dumas and André Wanderley do Prado for their help and support. We thank
Ana M.P.T. Carvalho-e-Silva, Clarissa Canedo, Daniel Fernandes, Fábio Hepp, Leandro Sabagh, and Manuella Folly for their useful comments to improve the manuscript. We thank the anonymous reviewer for the comments and suggestions to improve the manuscript, and to the editors Jaime Bertoluci, J. Roger Downie and Linda Trueb for their comments and English corrections. AMB thanks Coordenação de Aperfeiçoamento de Pessoal de Nível Superior (CAPES) and Fundação de Amparo à Pesquisa do Estado do Rio de Janeiro (FAPERJ) for the financial support. BG thanks CAPES for the financial support and Conselho Nacional de Desenvolvimento Científico e Tecnológico (CNPq) for the scholarship. This work was carried out with the license numbers \#69339-1 and \#65470-1.

\section{References}

Aguiar, A., D. H. Morais, P. J. P. Cicchi, and R. J. Silva. 2014. Evaluation of helminths associated with 14 amphibian species from a Neotropical island near the southeast coast of Brazil. Herpetological Review 45: $13-17$.

Almeida, B. C., R. S. Santos, T. F. Santos, M. B. Souza, M. B., and M. Menin. 2019. Diet of five anuran species in a forest remnant in eastern Acre state, Brazilian Amazonia. Herpetology Notes 12: 945-952.

Anderson, M. T. and A. Mathis. 1999. Diets of two sympatric neotropical salamanders, Bolitoglossa mexicana and $B$. rufescens, with notes on reproduction for B. rufescens. Journal of Herpetology 33: 601-607.

Araújo, A. P., C. M. Bastos, R. V. I. Santos, G. J. B. Moura, M. Melo-Júnior, and M. S. Tinoco. 2019. Novel records of phoresy among microcrustaceans and bromeliad treefrogs in the Atlantic Rainforest of Northeast Brazil. Herpetology Notes 12: 532-535.

Batista, R. C., C. B. De-Carvalho, E. B. Freitas, S. C. Franco, C. C. Batista, W. A. Coelho, and R. G. Faria. 2011. Diet of Rhinella schneideri (Werner, 1894) (Anura: Bufonidae) in the Cerrado, Central Brazil. Herpetology Notes 4: 017-021.

Brusca, R. C., W. Moore, and S. M. Shuster (eds.). 2016. Invertebrates. Sunderland, Massachusetts. Sinauer Associates. 1104 pp. 
Campião, K. M., A. C. Aquino Ribas, D. H. Morais, R. J. Silva, and L. E. R. Tavares. 2015. How many parasites species a frog might have? Determinants of parasite diversity in south american anurans. PLOS ONE 10: $1-12$.

Campião, K. M., I. C. O. Silva, G. T. Dalazen, F. Paiva, and L. E. R. Tavares. 2016. Helminth parasites of 11 anuran species from the Pantanal Wetland, Brazil. Comparative Parasitology 83: 92-100.

Campião, K. M., D. H. Morais, O. T. Dias, A. Aguiar, G. M. Toledo, L. E. R. Tavares, and R. J. Silva. 2014. Checklist of helminth parasites of amphibians from South America. Zootaxa 3843: 1-93.

Castroviejo-Fisher, S., J. M. Padial, I. De la Riva, J. P. Pombal Jr., H. R. Silva, F. J. M. Rojas-Runjaic, E. Medina-Méndez, and D. R. Frost. 2015. Phylogenetic systematics of egg-brooding frogs (Anura: Hemiphractidae) and the evolution of direct development. Zootaxa 4004: $1-75$.

Crump, M. L. 1974. Reproductive strategies in a tropical anuran community. Miscellaneous Publications of the Museum of Natural History, University of Kansas 61: $1-78$.

Das, I. 1996. Folivory and seasonal changes in diet in Rana hexadactyla (Anura, Ranidae). Journal of Zoology 238: 785-794.

del Pino, E. M. 2018. The extraordinary biology and development of marsupial frogs (Hemiphractidae) in comparison with fish, mammals, birds, amphibians and other animals. Mechanisms of Development 154: 2-11.

Duellman, W. E. and P. Gray. 1983. Developmental biology and systematics of the Egg-brooding hylid frogs, genera Flectonotus and Fritziana. Herpetologica 39: 333-359.

Duellman, W. E. and L. Trueb. 1994. Biology of Amphibians. Baltimore. The Johns Hopkins University Press. 670 pp.

Folly, M., F. Hepp, and S. P. Carvalho-e-Silva. 2018. A new bromeligenous species of Fritziana Mello-Leitão, 1937 (Amphibia: Anura: Hemiphractidae) from high elevations in the Serra dos Órgãos, Rio de Janeiro, Brazil. Herpetologica 74: 58-72.

Folly, M., F. Hepp, S. P. Carvalho-e-Silva, and W. E. Duellman. 2014. Taxonomic status and redescription of Flectonotus ulei (Anura: Hemiphractidae), with a key for the species of Fritziana. Zoologia 31: 393-399.

Freitas, E. B., C. B. De-Carvalho, R. G. Faria, R. C. Batista, C. C. Batista, W. A. Coelho, and A. Bocchiglieri. 2008. Nicho ecológico e aspectos da história natural de Phyllomedusaazurea(Anura: Hylidae: Phyllomedusinae) no Cerrado do Brasil Central. Biota Neotropica 8: 101110 .
Frost, D. R. (ed). 2020. Amphibian Species of the World: An online reference. Version 6.0 (10 April 2020). Electronic database accessible at http://research.amnh.org/ herpetology/amphibia/index.html. American Museum of Natural History, New York, USA. Captured on 10 November 2020.

Goldberg, S. R. and C. R. Bursey. 2019. Gastrointestinal helminths of three species Limnonectes frogs (Anura: Dicroglossidae) from Malaysia. Comparative Parasitology 86: 149-152.

Guarabyra, B., A. M. Bezerra, A. Galvão, and S. P. Carvalhoe-Silva. 2020. First record of ostracod ingestion by adult frogs. Cuadernos de Herpetología 34: 1-3.

Haddad, C. F. B. 1991. Ecologia Reprodutiva de uma Comunidade de Anfíbios Anuros na Serra do Japi, Sudeste do Brasil. Unpublished PhD Thesis. Universidade Estadual de Campinas, Brazil.

Haddad, C. F. B. and C. P. A. Prado. 2005. Reproductive modes in frogs and their unexpected diversity in the Atlantic Forest of Brazil. BioScience 55: 207-217.

Han, X. and J. Fu. 2013. Does life history shape sexual size dimorphism in anurans? A comparative analysis. BMC Evolutionary Biology 13: 1-11.

Houck, M. A. and B. M. O’Connor. 1991. Ecological and evolutionary significance of phoresy in the Astigmata. Annual Review of Entomology 36: 611-636.

Hsieh, T. C., K. H. Ma, and A. Chao. 2020. iNEXT. interpolation and extrapolation for species diversity. $\mathrm{R}$ package version 2.0.20. URL: http://chao.stat.nthu.edu. tw/wordpress/software_download/.

ICMBio 2020. Parque Nacional da Tijuca: O Parque. https:// parquenacionaldatijuca.rio/o-parque/. Captured on 07 May 2021.

IUCN 2021. The IUCN Red List of Threatened Species. Version 2021-1. https://www.iucnredlist.org. Captured on 07 May 2021.

Kehr, A. I. and M. I. Hamann. 2003. Ecological aspects of parasitism in the tadpole of Pseudis paradoxa from Argentina. Herpetological Review 34: 336-341.

Kitching, R. L. 2000. Food Webs and Container Habitats: The Natural History and Ecology of Phytotelmata. Cambridge. Cambridge University Press. 448 pp.

Kittel, R. N. and M. Solé. 2015. Diet of the striped snouted treefrog Scinax squalirostris (Anura, Hylidae) in southern Brazil. Herpetology Notes 8: 157-160.

Leivas, P. T., F. W. T. Leivas, and K. M. Campião. 2018. Diet and parasites of the anuran Physalaemus cuvieri Fitzinger, 1826 (Anura: Leiuperidae) from an Atlantic Forest fragment. Herpetology Notes 11: 109-113. 
Lopez, L. C. S., B. Filizola, I. Deiss, and R. I. Rios. 2005. Phoretic behavior of bromeliad annelids (Dero) and ostracods (Elpidium) using frogs and lizards as dispersal vectors. Hydrobiologia 549: 15-22.

Lopez, L. C. S., D. A. Gonçalves, A. Mantovani, and R. I. Rios. 2002. Bromeliad ostracods pass through amphibian (Scinax perpusillus) and mammalian guts alive. Hydrobiologia 485: 209-211.

Malagoli, L. R., T. L. Pezzuti, D. L. Bang, J. Faivovich, M. L. Lyra, J. G. R. Giovanelli, P. C. A. Garcia, R. J. Sawaya, and C. F. B. Haddad. 2021. A new reproductive mode in anurans: Natural history of Bokermannohyla astartea (Anura: Hylidae) with the description of its tadpole and vocal repertoire. PLOS ONE 16: 1-30.

Martins, A. C. J. S., M. C. Kiefer, C. C. Siqueira, M. Van Sluys, V. A. Menezes, and C. F. D. Rocha. 2010. Ecology of Ischnocnemaparva (Anura: Brachycephalidae) at the Atlantic Rainforest of Serra da Concórdia, state of Rio de Janeiro, Brazil. Zoologia 27: 201-208.

Mendonça, N. A., C. F. Moser, M. Oliveira, and C. F. D. Tozetti. 2020. Diet of Ololygon catharinae (Anura, Hylidae) during the breeding season. Herpetology Notes 13: 89-91.

Minchella, D. J. and M. E. Scott. 1991. Parasitism: a cryptic determinant of animal community structure. Trends in Ecology and Evolution 6: 1-5.

Moroti, M. T., E. Muscat, M. Pedrozo, I. F. Machado, L. T. Sabagh, and D. J. Santana. 2019. Interaction between ostracods and anurans: A review and new records in Brazil. Phyllomedusa 18: 269-275.

Moser, C. F., M. Oliveira, F. R. Avila, D. Dutra-Araújo, R. K. Farina, and A. M. Tozetti. 2019. Diet and trophic niche overlap of Boana bischoffi and Boana marginata (Anura: Hylidae) in southern Brazil. Biota Neotropica 19: $1-6$.

Müller, K. and H. Wickham. 2020. Tibble. Simple data frames. R package version 3.0.4. URL: https://CRAN.Rproject.org/package=tibble.

Oliveira, M., F. R. Avila, and A. M. Tozetti. 2017. Diet of Rhinella arenarum (Anura, Bufonidae) in a coastal habitat in southern Brazil. Herpetology Notes 10: $507-$ 510 .

Oliveira, M. G. N., C. F. D. Rocha, and T. Bagnall. 1994. A comunidade animal associada à bromélia-tanque Neoregelia cruenta (R. Graham) L. B. Smith. Bromélia 1: $22-29$.

Pacheco, E. O., V. G. Ferreira, and R. M. H. Carvalho. 2017. Diet of Boana albopunctata (Anura: Hylidae) in an Atlantic Forest fragment of southeastern Brazil. Phyllomedusa 16: 57-62.
Pombal, J. P. Jr. and C. F. B. Haddad. 2005. Estratégias e modos reprodutivos de anuros (Amphibia) em uma poça permanente na Serra de Paranapiacaba, Sudeste do Brasil. Papéis Avulsos de Zoologia 45: 215-229.

Praderio, M. J. and M. D. Robinson. 1990. Reproduction in the toad Colostethus trinitatus (Anura: Dendrobatidae) in a northern Venezuela seasonal environment. Journal of Tropical Ecology 6: 333-341.

Prado, C. P. A., M. Uetanabaro, and F. S. Lopes. 2000. Reproductive strategies of Leptodactylus chaquensis and L. podicipinus in the Pantanal, Brazil. Journal of Herpetology 34: 135-139.

R Core Team. 2020. R. A language and environment for statistical computing. R Foundation for Statistical Computing. Vienna, Austria. URL: https://www.R-project. org/.

Rafael, J. A., G. A. R. Melo, C. J. B. Carvalho, S. A. Casari, and R. Constantino (eds.). 2012. Insetos do Brasil: Diversidade e Taxonomia. Ribeirão Preto. Holos Editora. $810 \mathrm{pp}$.

Rodrigues, D. J., S. F. Lopes, and M. Uetanabaro. 2003. Padrão reprodutivo de Elachistocleis bicolor (Anura, Microhylidae) na Serra da Bodoquena, Mato Grosso do Sul, Brasil. Iheringia, Série Zoologia 93: 365-371.

Rudis, B. 2020. Hbrthemes. Additional themes, theme components and utilities for 'ggplot2'. R package version 0.8.0. URL: https://CRAN.R-project.org/ package $=$ hrbrthemes.

Sabagh, L. T. and C. F. D. Rocha. 2014. Bromeliad treefrogs as phoretic hosts of ostracods. Naturwissenschaften 101: 493-497.

Sabagh, L. T., R. B. Ferreira, and C. F. D. Rocha. 2017. Host bromeliads and their associated frog species: Further considerations on the importance of species interactions for conservation. Symbiosis 73: 201-211.

Sabagh, L. T., R. J. P. Dias, C. W. C. Branco, and C. F. D. Rocha. 2011. New records of phoresy and hyperphoresy among treefrogs, ostracods, and ciliates in bromeliad of Atlantic forest. Biodiversity Conservation 20: 1837-1841.

Sabagh, L. T., G. L. Ferreira, C. W. C. Branco, C. F. D. Rocha, and N. Y. N. Dias. 2012. Larval diet in bromeliad pools: a case study of tadpoles of two species in the genus Scinax (Hylidae). Copeia 2012: 683-689.

Sant'Anna Neto, J. L. 2005. Decálogo da climatologia do sudeste brasileiro. Revista Brasileira de Climatologia 1: 43-60.

Shine, R. 1979. Sexual selection and sexual dimorphism in the Amphibia. Copeia 1979: 297-306. 
Silva, H. R. and M. C. Britto-Pereira. 2006. How much fruit do fruit-eating frogs eat? An investigation on the diet of Xenohyla truncata (Lissamphibia: Anura: Hylidae). Journal of Zoology 270: 692-698.

Simon, M. and C. Toft. 1991. Diet specialization in small vertebrates: mite-eating in frogs. Oikos 61: 263-278.

Solé, M. and D. Rödder. 2009. Dietary assessments of adult amphibians. Pp. 167-184 in C. K. Dodd Jr. (ed.), Amphibian Ecology and Conservation. A Handbook of Techniques. Oxford University Press.

Solé, M., O. Beckmann, B. Pelz, A. Kwet, and W. Engels. 2005. Stomach-flushing for diet analysis in anurans: an improved protocol evaluated in a case study in Araucaria forests, southern Brazil. Studies on Neotropical Fauna and Environment 40: 8-23.

Tavares, L. E. R., K. M. Campião, R. Costa-Pereira, and F. Paiva. 2016. Helmintos endoparasitas de vertebrados silvestres em Mato Grosso do Sul, Brasil. Iheringia, Série Zoologia 107: 1-14.

Teixeira, C. C. L., M. Hoffmann, and G. Silva-Filho. 2009. Comunidade de Coleoptera de solo em remanescente de Mata Atlântica no Estado do Rio de Janeiro, Brasil. Biota Neotropica 9: 91-95.

Teixeira, R. L. and D. Vrcibradic. 2003. Diet of Leptodactylus ocellatus (Anura: Leptodactylidae) from coastal lagoons of southeastern Brazil. Cuadernos de Herpetología 17: $111-118$.

Toft, C. A. 1980. Feeding ecology of thirteen syntopic species of anurans in a seasonal tropical environment. Oecologia 45: 131-141.

Toft, C. A. 1981. Feeding ecology of Panamanian litter anurans: Patterns in diet and foraging mode. Journal of Herpetology 15: 139-144.
Triplehorn, C. A., N. F. Johnson, and D. J. Borror (eds.). 2005. Borror and Delong's Introductions to the Study of Insects. Belmont. Thompson Brooks/Cole. 888 pp.

Vaz-Silva, W., J. G. Frota, P. H. Prates-Júnior, and J. S. B. Silva. 2005. Dieta de Lysapsus laevis Parker, 1935 (Anura: Hylidae) do médio rio Tapajós, Pará, Brasil. Comunicações do Museu de Ciências e Tecnologia da PUCRS, Série Zoologia 18: 3-12.

Walker, M., J. L. Gasparini, and C. F. B. Haddad. 2016. A new polymorphic species of egg-brooding frog of the genus Fritziana from southeastern Brazil (Anura, Hemiphractidae). Salamandra 52: 221-229.

Walker, M., M. L. Lyra, and C. F. B. Haddad. 2018. Phylogenetic relationships and cryptic species diversity in the Brazilian egg-brooding tree frog, genus Fritziana Mello-Leitão 1937 (Anura: Hemiphractidae). Molecular Phylogenetics and Evolution 123: 59-72.

Weygoldt, P. 1989. Feeding behavior of the larvae of Fritziana goldii (Anura, Hylidae). Amphibia-Reptilia 10: 419-422.

Weygoldt, P. and S. P. Carvalho-e-Silva. 1991. Observations on mating, oviposition, egg sac formation and development in the egg-brooding frog, Fritziana goeldii. Amphibia-Reptilia 12: 67-80.

Wickham, H. 2007. Reshaping data with the reshape package. Journal of Statistical Software 21: 1-20.

Wickham, H. 2016. Ggplot2. Elegant Graphics for Data Analysis. Springer-Verlag New York. ISBN 978-3-31924277-4. URL: https://ggplot2.tidyverse.org.

Woolbright, L. L. 1983. Sexual selection and size dimorphism in anuran Amphibia. American Naturalist 121: 110119.

Editor: J. Roger Downie

Appendix I. Specimens collected and deposited in the amphibian collection of Laboratório de Anfíbios e Répteis, Departamento de Zoologia, Instituto de Biologia, Universidade Federal do Rio de Janeiro (ZUFRJ).

Fritziana goeldii, Parque Nacional da Tijuca: ZUFRJ 16774, 16791, 16773, 16786, 16775, 16777, 16597, 16787, 16593, 16602, 16659, 16794, 16785, 16797, 16822, 16823, 16772, 16600, 16796, 16599, 16778, 16655, 16594, 16780, 16793, 16782, 16792, 16658, 16776, 16824, 16598, 16788, 16783, 16591, 16656, 16789, 16601, 16595, 16795, 16790, 16784, 16590, 16589, $16781,16592,16596,16821,16657,16779,16529,16603,51,52,53,54,55,15831,15830,16552,16553,15942,16403$, $16551,16406,15943,16554,15944,16540,16550,16070,16530,16405,15832,16555,16531$. 